Portland State University

PDXScholar

Spring 5-30-2014

\title{
Seasonal and Sex Differences in the Effects of Melatonin on Brain Arginine Vasotocin in Green Treefrogs (Hyla cinerea): Relationship to Melatonin Receptor 1a
}

Christina Marie Howard

Portland State University

Follow this and additional works at: https://pdxscholar.library.pdx.edu/open_access_etds

Part of the Neuroscience and Neurobiology Commons

Let us know how access to this document benefits you.

\section{Recommended Citation}

Howard, Christina Marie, "Seasonal and Sex Differences in the Effects of Melatonin on Brain Arginine Vasotocin in Green Treefrogs (Hyla cinerea): Relationship to Melatonin Receptor 1a" (2014). Dissertations and Theses. Paper 1871.

https://doi.org/10.15760/etd.1871

This Thesis is brought to you for free and open access. It has been accepted for inclusion in Dissertations and Theses by an authorized administrator of PDXScholar. Please contact us if we can make this document more accessible: pdxscholar@pdx.edu. 
Seasonal and Sex Differences in the Effects of Melatonin on Brain Arginine Vasotocin in Green Treefrogs (Hyla cinerea): Relationship to Melatonin Receptor 1a

by

Christina Marie Howard

A thesis submitted in partial fulfillment of the requirements for the degree of

\author{
Master of Science \\ in \\ Biology
}

Thesis Committee:

Deborah I. Lutterschmidt, Chair

Randy Zelick

Bradley Buckley

Portland State University

2014 


\begin{abstract}
$\underline{\text { Abstract }}$
Critical life history events such as breeding, migration and hibernation must take place in the correct environmental context to minimize deleterious consequences on survival and reproductive fitness. Neuroendocrine mechanisms synchronizing internal physiological states with extrinsic environmental cues are vital to timing life history events appropriately. Secretion of the pineal hormone melatonin is sensitive to light and temperature cues, which provides a physiological indicator of time of day and time of year for organisms. Melatonin influences seasonal reproduction in a variety of vertebrates, likely by altering the synthesis and/or release of reproductive neuropeptides in the brain. The neuropeptides arginine vasotocin and its mammalian homologue, arginine vasopressin, are well-known modulators of reproductive and sociosexual behavior across vertebrate taxa, and are likely targets of melatonin in the context of seasonal reproduction. There is extensive evidence that vasotocin/vasopressin innervation in the brain is subject to seasonal variation, and that this variation is frequently sexually dimorphic. However, evidence that melatonin directly modulates this important neuropeptide system is lacking. Melatonin receptor 1a (MT1 in mammals) may be responsible for mediating melatonin's influence on brian vasotocin, as it is known to regulate seasonal reproduction in a variety of vertebrates. In the present study, I asked whether melatonin influences brain vasotocin in male green treefrogs (Hyla cinerea), and compared the distribution of melatonin receptor 1a in the brain of green treefrogs between sexes and seasons. Adult male and female green treefrogs were collected from field sites in Louisiana during the summer breeding season. Summer animals were
\end{abstract}


acclimated to lab conditions for 3 weeks, then euthanized and their brains collected. Winter animals were maintained in the lab for four months under incrementally changing photo-, thermo-, and hygroperiod regimes that mimicked the transition to winter in their natural habitat, followed by euthanasia and brain collection. A subset of winter males (Experiment 1) were implanted with melatonin-filled or blank silastic capsules for a period of one month prior to euthanasia and brain collection. Brains of these males were processed for vasotocin immunohistochemistry. I quantified AVT-ir cell number in Experiment 1 males in the nucleus accumbens (NAcc), amygdala and caudal striatum (AMG), preoptic area (POA), suprachaismatic nucleus ( $\mathrm{SCN})$, and ventral hypothalamus (VH). Melatonin did not influence brain vasotocin-ir cell number in any brain region. Brains from untreated summer and winter males and females were collected and processed for MT1 immunohistochemistry. MT1-ir cells were quantified in the NAcc, striatum (STR), AMG, POA, SCN, and VH. In all regions quantified, reproductively active males had significantly more MT1-ir cells than nonreproductive males. Within the summer breeding season, males had significantly more MT1-ir cells in the NAcc than did reproductively active females. In all other regions there was no significant difference in MT1-ir cell number between reproductively active males and females. Collectively, these data suggest that melatonin modulates vasotocin via MT1. These findings assist in elucidating the neuroendocrine mechanisms by which vertebrates integrate seasonal cues with physiology to correctly time critical life history events. 


\section{Acknowledgements}

I'd like to thank my Advisor, Dr. Deborah Lutterschmidt for her patience and support throughout my somewhat atypical journey toward earning my Master of Science, and my committee members Dr. Randy Zelick and Dr. Bradley Buckley for their input and encouragement in this endeavor. I would also like to thank my colleague, lab mate, and partner in minor miscreant activity Catherine Dayger: Cat, I would not have made it through this without you, and thank you for putting up with my office lunacy and for supporting me when things got tough. Thank you to Ashley Maine for technical expertise and collegial support as well! I'd be remiss not to thank the BioBabes and BioBros (copyright pending), members of my cohort who formed an important support network these past three years. These are Kessina Lee, Claire Riggs, Kyle Tidwell, Monte Mattson, and James Powell. Finally, I would like to take this opportunity to thank the American Society of Ichthyologists and Herpetologists Gaige Fund Award, and the Forbes-Lea Award for financial support of my research. 


\section{Table of Contents}

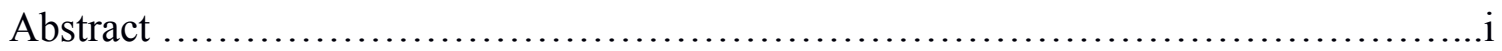

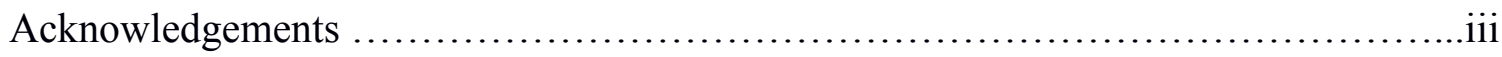

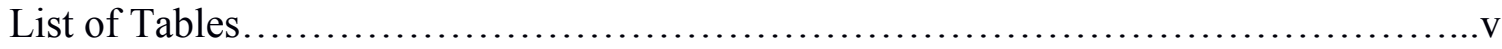

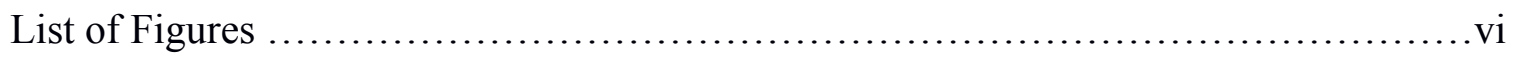

Introduction and literature review...............................................

Materials and Methods: ..............................................................

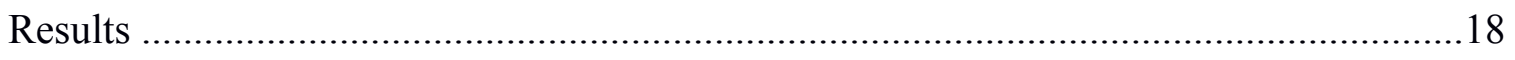

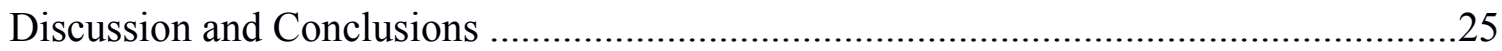

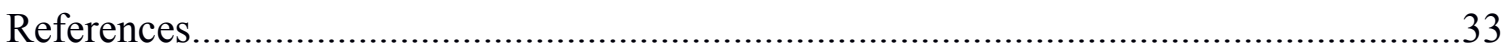




\section{List of Tables}

Table 1. Photoperiod, temperature, and humidity regimes used for acclimatization of green treefrogs (Hyla cinerea). 


\section{List of Figures}

Figure 1. Distribution of vasotocin-ir cells in nonreproductive male green treefrogs (Hyla cinerea) following melatonin treatment

Figure 2. Distribution of MT1 immunoreactivity in green treefrogs (Hyla cinerea).

Figure 3. Example photomicrographs of MT1 antiserum preabsorption tests.

Figure 4. Seasonal and sex differences in MT1-ir cell number in green treefrogs (Hyla cinerea). 


\section{INTRODUCTION AND LITERATURE REVIEW}

\section{Timing of critical life-history events}

Behaviors such as reproduction, feeding, and migration are critical life-history events for a wide range of vertebrates, many of which perform these behaviors only at particular times of year. In a popular example of seasonal behavior, bears and other mammals hibernate during the winter, when temperatures are low and food is often scarce. Conversely, animals occupying xeric environments often estivate underground or in caves to avoid high temperatures and minimize water loss during the hottest part of the year. In these cases, the behavior in question must be performed in a particular environmental context, which is determined by a combination of environmental conditions such as temperature, humidity, day length, and food availability. Mistiming critical life history events and behaviors can have serious consequences on survival and reproductive fitness. For example, failure to migrate or reproduce at the correct time of year can result in parturition of young during times of unfavorable climate or food shortage. In one study of a migratory passerine, collared flycatchers (Ficedula albicollis) that laid eggs past the average first-egg date hatched chicks out-of-sync with the yearly peak in caterpillar abundance (their major food source) at their breeding grounds. Late hatchlings showed reduced capacity for compensatory weight gain as adults relative to on-time hatchlings (2). In this example, mistimed reproduction had significant consequences on the physiology of offspring, persisting even into adulthood. This example is just one of many illustrating the importance of coordinating seasonal 
physiological rhythms with external environmental cues such as food availability, photoperiod, and social signals.

\section{Neuroendocrine regulation of biological timekeeping: Role of melatonin}

Neuromodulators and hormones are crucial signaling molecules that regulate physiology and organize behaviors. Accordingly, the neuroendocrine mechanisms by which animals synchronize their intrinsic physiological state with extrinsic environmental cues are vital to timing life-history events appropriately. One important endocrine transducer of environmental cues with respect to biological timekeeping is the indoleamine hormone melatonin, secretion of which is directly sensitive to photoperiod and temperature (3-7). Melatonin is synthesized primarily in the pineal gland, but also in the alimentary canal and Harderian glands (8). Regardless of the site of synthesis, melatonin is secreted only during scotophase (in darkness), such that the phase of the melatonin pulse encodes time of day, and the duration of elevated melatonin concentrations encodes day length $(9,10)$. Further, this photoperiodic pattern of melatonin secretion is highly conserved across taxa; regardless of temporal niche or site of synthesis, melatonin synthesis is inhibited by light, and therefore begins at the onset of darkness (10). Other environmental cues also influence melatonin synthesis and secretion. For example, in many ectotherms, such as Diamondback watersnakes (Nerodia rhombifer) and red-sided gartersnakes (Thamnophis sirtalis parietalis), decreased temperature depresses the amplitude of the nightly melatonin pulse, but the duration of the pulse is unaffected, providing even more specific information about environmental conditions $(11,12)$. Therefore, it is the overall rhythm of melatonin synthesis and 
secretion, including the phase, duration and amplitude, that provides information about day length, day and night onset, and temperature. The result is a season-specific rhythm of melatonin secretion that organisms can use to synchronize their physiology and behavior with seasonally-changing environmental conditions.

\section{Role of melatonin in regulating seasonal reproduction}

Not surprisingly, melatonin influences seasonal reproduction in a variety of vertebrates $(6,13)$. Among the most well studied of these are sheep, whose extensivelydocumented short-day breeding behavior is regulated principally by photoperiod-induced changes in melatonin (14). Pinealectomized Suffolk ewes showed similar reproductive responses to those of unaltered short-day or long-day ewes when infused with melatonin in patterns mimicking short or long photoperiods, respectively. Thus, changes in the melatonin pulse duration are sufficient to induce reproductive condition in these animals (15-17). In male green anoles (Anolis carolinensis), neither pinealectomy nor melatonin treatment influenced photoperiodic gonadal responses during the summer. However, during the winter, pinealectomy resulted in seasonal gonadal development, an effect that was blocked by subsequent treatment with melatonin (18). Therefore, in anoles, the sensitivity of gonadal processes to melatonin is itself seasonally modulated. Thus, although melatonin appears to regulate reproduction in some vertebrate groups, reproductive responses to melatonin treatment and/or pinealectomy vary both seasonally and across taxa. Accordingly, although melatonin itself is well-studied the molecular mechanisms by which melatonin influences vertebrate reproduction remain enigmatic. 


\section{Neuropeptide regulation of seasonal reproduction}

One possible mechanism by which melatonin may influence reproductive behavior is by altering the synthesis and/or release of reproductive neuropeptides in the brain (1, 19-21). By altering neuropeptide signaling, melatonin could thereby synchronize the regulation of reproduction with optimal environmental cues. The neuropeptide arginine vasotocin (vasotocin) and its mammalian homologue, arginine vasopressin (vasopressin), are likely targets of melatonin in this context, as they are well-known modulators of reproductive and social behavior (22-25). Vasopressin, also known as antidiuretic hormone $(\mathrm{ADH})$ for its role in regulating vascular tone and water retention, was originally identified by Wolfgand Bargmann and Ernst Scharrer in 1951 as a product of neurosecretory cells in the hypothalamus (26). It was subsequently discovered that in addition to being synthesized in the hypothalamus (specifically the pre-optic area and the suprachiasmatic nucleus), vasotocin/vasopressin neuron populations have also been identified in the amygdala, nucleus accumbens and striatum $(23,27,28)$. While the neurosecretory vasotocin cells of the pre-optic area of the hypothalamus are wellunderstood to exert pressor effects and regulate water balance, the specific function of the other populations of vasotocin neurons remains enigmatic. However, neurohypophyseal hormones such as vasotocin and vasopressin can act on target neurons within the brain to influence neuronal firing rate (29). For example, injection of vasotocin via microionophoresis significantly decreased spontaneous neuronal firing in the rat brain (30). Overall, the neuromodulatory vasotocin and vasopressin have been found to be 
critical in regulating social and reproductive behavior across vertebrate taxa, and likely regulate these behaviors via localized modulation of nearby neurons (reviewed in 22, 31).

A large body of work shows that treatment with exogenous vasotocin or vasopressin induces appetitive reproductive behavior in males of many vertebrate species including fish, anuran and urodelan amphibians, birds and mammals (22-24, 27, 32-37). For example, injection of exogenous vasotocin induces advertisement calling in many frogs $(24,33,38-40)$ and courtship behavior, including clasping, in the rough skinned newt (Taricha granulosa) $(34,41)$. Moreover, there is extensive evidence that the vasotocin/vasopressin neuropeptide system varies seasonally, with vasotocin/vasopressin neuron number being higher during the breeding season in many species $(22,25,42)$. Despite ample evidence that vasotocin and vasopressin are modulated seasonally, and that these nonapeptides are potent regulators of social reproductive behavior, few studies have directly investigated melatonin's influence on the vasotocin/vasopressin neuropeptide system in vivo or in vitro $(19,20,43)$.

\section{Influence of melatonin on the vasotocin/vasopressin neuropeptide system}

Given the crucial role of vasotocin and vasopressin in seasonal reproduction, these neuropeptides are potentially important targets of melatonin in synchronizing seasonal reproductive behavior with optimal environmental conditions. For example, in the long-day breeding (approximately April-May) green treefrog (Hyla cinerea), treatment of reproductively active males with melatonin significantly decreased vasotocin-immunoreactive (-ir) cell number in the nucleus accumbens (NAcc) and the suprachiasmatic nucleus ( $\mathrm{SCN})$, two brain regions associated with appetitive reproductive 
behavior and circadian timing, respectively (1). Males of this species gather and call in leks to attract females, and must time this behavior correctly in order to reproduce successfully (44). Thus, regulation of vasotocin within the NAcc and SCN is probably critical for matching breeding behavior with the appropriate social and environmental context. Interestingly, not all vasotocin neuron populations were sensitive to melatonin signaling in this study. Other vasotocin neuron populations in this species, including the amygdala (AMG), pre-optic area (POA), and the ventral hypothalamus ( $\mathrm{VH})$ were not affected by melatonin treatment. Moreover, the effects of melatonin on vasotocin were sexually dimorphic, as females showed no change in vasotocin-ir cell number in any vasotocin neuron population in response to melatonin (1). Because males of this species typically have more vasotocin-ir cells during the summer breeding season, and more vasotocin-ir cells than females in general, these results indicate that melatonin's influence on brain vasotocin is both regionally specific and sexually dimorphic.

\section{Role of melatonin receptors in reproduction}

In the present study, I asked if melatonin also alters vasotocin-ir cell number in nonreproductive male green treefrogs in order to evaluate whether melatonin's observed modulation of brain vasotocin is seasonal in this species. Further, because the response of brain vasotocin to melatonin in green treefrogs is sexually dimorphic (1), I asked whether the observed variation in brain vasotocin's responsiveness to melatonin is related to differences in the distribution and/or number of neurons expressing melatonin receptor between sexes and seasons, especially in brain regions known to contain vasotocin neuron populations. Like most vertebrates, anuran amphibians possess three subtypes of 
membrane-bound, G-protein coupled melatonin receptors: Mel1a, Mel1b, and Mel1c (MT1, MT2, and MT3 in mammals) I focused my study on melatonin receptor 1a (also called MT1 in mammals) for these studies because of its well-known role in regulating seasonal reproduction in other vertebrates $(45,46)$. For example, Siberian hamsters (Phodopus sungorus) that express functional brain MT1, but not MT2, change reproductive state following treatment with a melatonin receptor agonist (46). In orangespotted grouper (Epinephelus coioides), decreased MT1 expression increases expression of gonadotrophin releasing hormone receptors and alters ovarian fecundity (45). In both of these examples, MT1 regulates reproduction, but whether this regulation is directly tied to seasonal modulation of vasopressin or vasotocin is unknown. In Siberian hamsters and humans (Homo sapiens), MT1 localizes within vasopressin neurons in the SCN, suggesting that melatonin can directly modulate vasopressin neurons via a receptormediated mechanism $(47,48)$. However, in both cases, the consequences of these observations on social or sexual behavior remain enigmatic.

Based on these collective findings, I broadly hypothesized that 1) melatonin's influence on brain vasotocin will vary seasonally, with brain vasotocin being less responsive to melatonin outside of the breeding season, and 2) brain MT1-ir cell number will vary with sex and season in seasonally breeding animals. In order to test these hypotheses, I used green treefrogs (Hyla cinerea) as a model organism due to their robust and quantifiable seasonal breeding behavior and physiology, and for their ease of capture and maintenance in a laboratory environment. Using green treefrogs, I asked the following questions: (1) Does melatonin alter the number of vasotocin-ir cells in the brain 
of nonreproductive males? and (2) Does the distribution of MT1 in vasotocin neuron populations vary between sexes and seasons? 


\section{MATERIALS AND METHODS}

These experiments were performed between July and November 2012 using adult green treefrogs $(H$. cinerea). Green treefrogs are native to the southeastern United States and breed between spring and late summer (approximately April through August). In order to attract females, males gather in lek-like aggregations and produce advertisement calls. Females do not call, but select mates from aggregations of calling males (44).

Male and female frogs were purchased from General Exotics, Inc. (Moore, Oklahoma); frogs were field-collected from natural breeding populations in Houma, Louisiana. At Portland State University, animals were housed in 10-gallon aquaria in same sex groups of 4-6 individuals within a microprocessor-controlled environmental chamber. All aquaria contained a hide box, water dish, and artificial foliage. Water was provided ad libitum and frogs were fed crickets 2-3 times per week; crickets were fed vitamin-fortified cricket food ad libitum (Fluker Farms, Inc.). All experimental and animal care protocols were approved by the Portland State University Animal Care and Use Committee (approval number psu12.05.02.1).

\section{EXPERIMENAL DESIGN}

\section{Experiment 1: Influence of melatonin on brain vasotocin}

In this experiment, I examined if melatonin affects vasotocin-ir cell number in nonreproductive male green treefogs. Due to the difficulty in collecting treefrogs during winter months, when they are typically dormant, I opted to collect reproductively active treefrogs during the breeding season and acclimatize them to increasingly winter-like environmental conditions using an environmental chamber. Upon arrival in the 
laboratory, male frogs were acclimatized for 4 weeks to a 13:11 h L:D photoperiod and 28:20 ${ }^{\circ} \mathrm{C}$ thermoperiod, which mimicked the environmental conditions in Houma, LA during mid-summer. Following this 4-week acclimatization period, photoperiod, temperature, and humidity were adjusted every 3-4 weeks for the next three months until conditions closely resembled those of Houma, LA in mid-winter (Table 1). Nonreproductive status of male frogs was confirmed by an absence of calling behavior and regression of male throat pouches that are indicative of summer breeding activity (i.e. calling). Male frogs were then randomly assigned to either a melatonin or control implant treatment ( $\mathrm{n}=8$ in each treatment group). The duration of hormone exposure was four weeks, such that winter-acclimatized frogs remained in the lab for a total of 20 weeks before tissue sampling. At the end of the 4-week treatment period, all frogs were euthanized and their brains collected for vasotocin immunohistochemistry.

\section{Experiment 2: Seasonal and sex variation in MT1 immunoreactivity}

In this experiment, I asked if seasonal and sex differences in the influence of exogenous melatonin on vasotocin cell number are associated with variation in MT1 immunoreactivity. I used a subset of male and female frogs for this experiment that were independent of those used in Experiment 1. Similar to our first experiment, frogs were acclimatized to a $13: 11 \mathrm{~h} \mathrm{~L}: \mathrm{D}$ photoperiod and $28: 20^{\circ} \mathrm{C}$ thermoperiod upon arrival in the laboratory, thereby mimicking the environmental conditions in Houma, LA during midsummer. Following a 3-week acclimatization period, a randomly-selected subset of reproductively active, summer-acclimated frogs ( $\mathrm{n}=14$ males, 6 females) were euthanized and their brains collected. The remaining animals were maintained in our 
environmental chamber and incrementally acclimatized to winter-like conditions over a period of 3 months (Table 1). Non-reproductive, winter-acclimatized frogs $(\mathrm{n}=13$ males, 3 females) were then euthanized and their brains collected for MT1 immunohistochemistry.

\section{HORMONE MANIPULATION}

As in Lutterschmidt and Wilczynski [2012], I used melatonin-filled silastic capsules to artificially elevate melatonin in male green treefrogs in Experiment 1. Short lengths of silastic tubing $(5 \mathrm{~mm}$ length $\times 0.76 \mathrm{~mm}$ inner diameter $\times 1.65 \mathrm{~mm}$ outer diameter $)$ were packed with crystalline melatonin (Sigma, St. Louis, MO., USA). Control implants were identical in size to melatonin implants but were left empty. Both ends of the silastic capsules were sealed with medical-grade silicone sealant (Dow Corning, Midland, MI., USA). Frogs were anaesthetized by submersion in $0.2 \%$ methylsulfonic acid (MS-222) in amphibian Ringer's solution ( $\mathrm{pH}$ 7.2) for 5-7 minutes, after which a small incision (approx. 2-3 mm) was made on the lateral side of each animal, just posterior to the forelimb and slightly dorsal to the yellowish-white lateral stripe that is characteristic of this species. This stripe is bilateral and generally runs rostro-caudally from the upper lip to just anterior to the hind legs. A silastic capsule was inserted subcutaneously through the incision, which was then closed using one suture and a small quantity of tissue glue (VetBond, 3M Inc., St. Paul, MN., USA). All surgeries were performed within the environmental chamber to ensure frogs were not exposed to changes in ambient temperature. Frogs were allowed to fully recover from anaesthesia before being returned to their home aquaria. In Experiment 1, all animals within an aquarium received the same 
hormone treatment and were housed separately from Experiment 2 frogs. During the 4week hormone treatment period, frogs were monitored daily to ensure that implants remained intact and proper healing occurred.

\section{TISSUE COLLECTION AND PROCESSING}

Frogs were euthanized by immersion in $0.4 \%$ MS-222 in amphibian Ringer's solution ( $\mathrm{pH}$ 7.2) for 4-10 minutes and rapidly decapitated. Implants from Experiment 1 animals were removed to confirm that they had remained intact for the duration of hormone treatment. Gonads of each animal were inspected to confirm sex after tissue sampling. Brains were fixed via immersion in $4 \%$ paraformaldehyde in $0.1 \mathrm{M}$ phosphate buffer ( $\mathrm{pH} 7.2$ ) for $16 \mathrm{~h}$ at $4^{\circ} \mathrm{C}$, then cryoprotected in $30 \%$ sucrose in $0.1 \mathrm{M}$ phosphate buffer. Brains were then sectioned into four series of $25-\mu \mathrm{m}$ coronal sections that were thaw-mounted onto subbed slides (Superfrost Plus, Thermo Fisher Scientific, Inc., Pittsburgh, PA., USA). Slides were stored at $-20^{\circ} \mathrm{C}$ prior to immunohistochemical staining.

\section{IMMUNOHISTOCHEMISTRY}

I used immunohistochemistry for vasotocin to examine melatonin's influence on vasotocin-ir cell number in nonreproductive male $H$. cinerea. Likewise, I used immunohistochemistry for MT1 to determine the distribution of MT1-immunoreactive cells in reproductive and non-reproductive male and female frogs. In Experiment 1, tissues were processed using two identical vasotocin assays; treatment groups were randomly distributed between assays. In Experiment 2, all tissues were processed in a 
single assay for MT1. Slides were thawed and dried on a slide warmer at $37^{\circ} \mathrm{C}$ for 30 minutes to enhance tissue adherence to slides. Tissues were further fixed to slides by immersion in $4 \%$ paraformaldehyde in $0.1 \mathrm{M}$ phosphate-buffered saline (PBS; $\mathrm{pH} 7.4$ ) for 5 minutes followed by washing 3 times for 5 minutes each in $0.1 \mathrm{M}$ PBS (pH 7.4). Fixative was neutralized by immersing slides in $0.1 \%$ sodium borohydride $(\mathrm{pH} 8.5)$ for 20 minutes followed by another series of PBS washes $(3 \times 5 \mathrm{~min})$. Endogenous peroxidases were quenched in $1 \%$ hydrogen peroxide in $0.1 \mathrm{M}$ PBS for 30 minutes. Slides were washed in PBS $(2 \times 5 \mathrm{~min})$ followed by PBS with $0.3 \%$ Triton X (PBS-T; pH $7.4 ; 1 \times 5 \mathrm{~min}$ ) and then incubated for 60 minutes in PBS-T containing $10 \%$ normal goat serum (Experiment 1) or 10\% normal horse serum (Experiment 2) and 10\% avidin (Vector Labs, Inc., Burlingame, CA., USA). The purpose of this step is to reduce binding of primary antibodies to molecules other than the peptide of interest, for example, endogenous biotin. Treatment of experimental tissue with normal animal sera containing greatly reduces nonspecific binding between the primary experimental antibody and nontarget peptides by binding up non-target peptides before the administration of the primary experimental antibody. Immunoreactive cells were labelled using a rabbit antivasopressin antiserum (primary antibody for Experiment 1, item 20069, Immunostar, Inc., Hudson, WI., USA) at a 1:5000 dilution or a goat anti-melatonin receptor 1a antiserum (primary antibody for Experiment 2, item sc13179, Santa Cruz Biotechnology, Inc., Dallas, TX., USA) at a 1:500 dilution. Primary antibodies were diluted in PBS-T containing 10\% serum and 10\% biotin (Vector Labs, Inc.). Slides were coverslipped and incubated with primary antibody in a humid chamber at $4^{\circ} \mathrm{C}$ for 48 hours, after which they were washed in PBS $(2 \times 5 \mathrm{~min})$ followed by PBS-T $(1 \times 5 \mathrm{~min})$. Amplification of 
the primary antibody signal was achieved by incubating slides for 60 minutes in biotinylated (covalently attached to biotin) goat anti-rabbit secondary antibody (for vasotocin in Exp. 1; BA-1000, Vector labs, Inc.) or biotinylated horse anti-goat secondary antibody (for MT1 in Exp. 2; BA 9500, Vector labs, Inc.) diluted 1:500 in 0.1M PBS-T. Sections were washed in PBS $(2 \times 5 \mathrm{~min})$ followed by PBS-T $(1 \times 5 \mathrm{~min})$, incubated in avidin-conjugated horseradish peroxidase (Elite ABC Peroxidase Kit, Vector Labs, Inc.) for 60 minutes, and rinsed in PBS $(2 \times 5 \mathrm{~min})$ followed by PBS-T $(1 \times 5 \mathrm{~min})$. Diaminobenzidine $(0.25 \mathrm{mg} / \mathrm{ml}$ in $0.2 \%$ hydrogen peroxide in $0.05 \mathrm{M}$ Tris- $\mathrm{HCl}$ buffer $)$ was used to visualize primary antibody binding. The chromogen reaction was halted by immersion in nanopure water $(3 \times 5 \mathrm{~min})$. Slides were then dehydrated in a graded ethanol series. The tissue was cleared with Citrisolv (Thermo Fisher Scientific, Inc.) and slides were sealed using permount (Thermo Fisher Scientific, Inc.) and glass coverslips. Vasotocin-ir cell and fibre populations have been described previously in several amphibians, including $H$. cinerea. $(25,27,49,50)$. By contrast, this is the first report of MT1 immunohistochemistry in a terrestrial anuran, although MT1 immunohistochemistry has been performed in Xenopus laevis, another anuran amphibian (51). To test for specificity of the MT1 antibody in $H$. cinerea, I performed a series of immunohistochemistry controls using preabsorption tests. Prior to MT1 immunohistochemistry, diluted goat anti-MT1 antiserum (1:500) was incubated overnight at $4^{\circ} \mathrm{C}$ with $0,1,6$ or $12 \mu \mathrm{g}$ MT1 peptide (sc13179P, Santa Cruz Biotechnology, Inc.) per $\mathrm{ml}$ antibody solution. I selected these peptide concentrations based on those used by Kharwar and Haldar (52). I used one male and one female frog for these tests, with one tissue series used for each peptide concentration. Both of these animals were independent 
from those used in Experiments 1 and 2. All tissue in the preabsorption test was processed in the same immunohistochemistry assay.

\section{IMMUNOREACTIVE CELL COUNTING}

Stained tissue sections were examined using an Olympus BX40 microscope with a QIClick digital camera and Q Capture Pro imaging software (Q Imaging, Surrey, B.C., Canada). Locations of vasotocin- or MT1-ir cell populations were mapped onto anatomical frog brain sections adapted from Neary and Northcutt (1983), and Wilczynski and Northcutt $(1983)(53,54)$. Immunoreactive cells within each region of interest were counted manually. Slides were coded to ensure the observer was blind to each animal's treatment group. If a tissue section was damaged or missing, the section was assigned the mean cell count of the immediately preceding and succeeding sections. If two or more consecutive tissue sections were damaged or absent, the animal was excluded from analysis for that region. Final sample sizes for each region of interest are shown in Figures 2 and 4.

Cells were identified as round or elliptical stained bodies, often with processes and/or vesiculated fibres extending from their somata. Locations of immunoreactive cells were mapped onto standard anatomical frog brain sections adapted from Neary and Northcutt (1983), and Wilczynski and Northcutt $(53,54)$ to assign regions of interest to observed cell populations. In all cases, the rostrocaudal progression of observed populations closely matched the shape of each assigned region in the literature. In the event that no distinct boundary was observed between two known regions, the regions were counted and quantified together. In all regions of interest, vasotocin-ir cells in each 
tissue section were quantified first under 200x magnification and then again under 400x magnification. Cell counts were usually identical, but occasionally differed by 1-3 cells. In these cases, the section was counted again under 400x. If the replicate count confirmed the previous cell number determined under 400x, that number was used as the final cell count for that section. If the replicate count again differed by 1-3 cells, the mean of the replicate cell counts was used as the final cell count for that section. The total number of immunoreactive cells in each brain region was quantified for each individual using one series of tissue. The whole brain of each animal in these studies was divided into 4 different series of $25-\mu \mathrm{m}$ sections, and therefore each section was separated by $100 \mu \mathrm{m}$ within a series. In the cell populations of interest, vasotocin-ir and MT1-ir cells are approximately $10 \mu \mathrm{m}$ or less in diameter, making double counting of cells split across two sections unlikely. In addition, cells were only counted if they were the same general size and shape of other cells within the regions of interest, thereby excluding partial cells from our cell counts.

\section{STATISTICS}

I first used a t-test to confirm that body size, measured as snout-urostyle length and used as a proxy for brain size, did not differ significantly between treatment groups in Experiment 1. In Experiment 2, I used a two-way analysis of variance (ANOVA) with sex and season as between-subjects factors to confirm that SUL did not differ significantly between groups. Prior to analysis, all cell count data were checked for normality and equal variance using the Shapiro-Wilk test; data were transformed as necessary. In Experiment 1, I determined whether melatonin influences vasotocin-ir cell 
number in non-reproductive male green treefrogs using a t-test within each region of interest. A non-parametric Mann-Whitney rank-sum test was used to test for differences in vasotocin-ir cell number in the NAcc, as transformation failed to correct for nonnormality in these data. In Experiment 2, I used t-tests within each region of interest to test for differences in MT1-ir cell number between seasons and sexes. Because our sample size of nonreproductive females is too small to produce reliable results via twoway ANOVA, I restricted our statistical analyses to compare MT1-ir cell number between 1) reproductive and nonreproductive males and 2) reproductive males and females during the summer breeding season. All statistical comparisons were considered significant at $\mathrm{p} \leq 0.05$. 
Table 1: Photoperiod, thermoperiod and hygroperiod regimes used for acclimatization of green treefrogs (Hyla cinerea) used in Experiments 1 and 2. Environmental chamber set points for photoperiod, thermoperiod, and hygroperiod based on meterological data for Houma, Louisana in 2011.

\begin{tabular}{llccc}
\hline $\begin{array}{l}\text { Acclimatization } \\
\text { Period }\end{array}$ & $\begin{array}{l}\text { Experimental } \\
\text { Timeline }\end{array}$ & $\begin{array}{c}\text { Photoperiod } \\
\text { (h L:D) }\end{array}$ & $\begin{array}{c}\text { Thermoperiod } \\
\left({ }^{\circ} \mathbf{C} \text { L:D) }\right.\end{array}$ & $\begin{array}{c}\text { Hygroperiod } \\
\text { (\%L:D) }\end{array}$ \\
\hline Wks 1-4 & $\begin{array}{l}\text { Animals arrive in lab; } \\
\text { summer-acclimatised } \\
\text { frogs for Exp. 2 }\end{array}$ & $13: 11$ & $28: 20$ & $90: 60$ \\
& euthanised wk 3. & & & \\
Wks 5-8 & & $13: 11$ & $24: 16$ & $90: 55$ \\
Wks 9-11 & & $12: 12$ & $20: 12$ & $85: 50$ \\
Wks 12-14 & & $11: 13$ & $15: 9$ & $85: 45$ \\
Wks 15-20 & $\begin{array}{l}\text { Experiment 1 males } \\
\text { implanted wk 16; all } \\
\text { winter animals for }\end{array}$ & $10: 14$ & $12: 4$ & $80: 50$ \\
& $\begin{array}{l}\text { Exps. 1 and 2 } \\
\text { euthanised wk 20 }\end{array}$ & & & \\
& & & &
\end{tabular}




\section{RESULTS}

\section{Experiment 1: Influence of Melatonin on vasotocin-ir cells}

Similar to previous studies $(1,25)$ I observed five discrete regions of vasotocin-ir staining in male frogs (Fig. 1). Immuoreactive cell bodies were quantified in the nucleus accumbens (NAcc), the medial and lateral amygdala (AMG), the anterior pre-optic area (POA), suprachiasmatic nucleus (SCN), and ventral hypothalamus (VH). I also observed immunoreactive cell bodies in the magnocellular region of the POA, but was unable to consistently discern the boundaries between this area and the anterior POA due to the very high number of stained cells in these regions. Accordingly, ir-cells counted within the magnocellular region of the POA were grouped with cell counts from the anterior POA for analysis. Similarly, vasotocin-ir cells were observed in the caudal striatum, but the boundaries between this region and the amygdala were frequently unclear, so cell counts from the AMG represent the combined data from the central and medial AMG and the caudal striatum. 

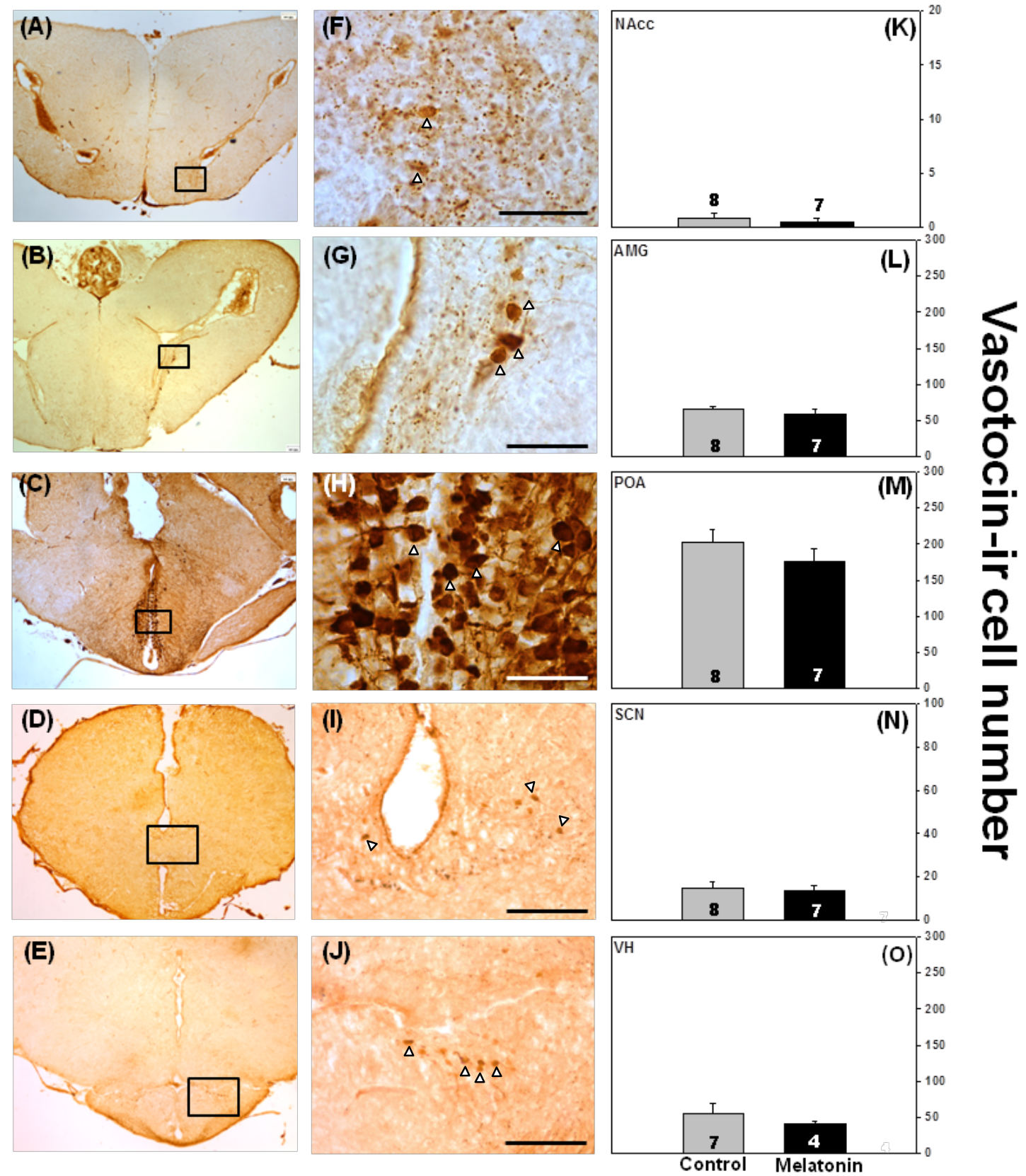

Fig. 1. Distribution of vasotocin-ir cells in nonreproductive male green treefrogs (Hyla cinerea). Example photomicrographs are brain tissue sections from the nucleus accumbens $(\mathrm{A}, \mathrm{F})$, medial and lateral amygdala $(\mathrm{B}, \mathrm{G})$, pre-optic area $(\mathrm{C}, \mathrm{H})$, suprachiasmatic nucleus $(\mathrm{D}, \mathrm{I})$, and ventral hypothalamus $(\mathrm{E}, \mathrm{J})$. Inset boxes in A-E (40x magnification) represent magnified spaces in F-J (400x magnification). Scale bars $=50 \mu \mathrm{m}$, arrows indicate immunoreactive cells. Bar graphs (K-L) show the influence of melatonin on vasotocin-ir cell number within the nucleus accumbens $(\mathrm{K})$, medial and lateral amygdala $(\mathrm{L})$, pre-optic area $(\mathrm{M})$, suprachiasmatic nucleus $(\mathrm{N})$, and ventral hypothalamus $(\mathrm{VH} ; \mathrm{O})$. For all regions, data are the mean number of vasotocin-ir neurons +1 SE. Sample sizes are listed within the bars above the $\mathrm{x}$-axis. 
Treatment with melatonin did not significantly alter vasotocin-ir cell number in non-reproductive male frogs in the NAcc (Fig. $1 \mathrm{C} ; \mathrm{U}=22.00, \mathrm{df}=13, \mathrm{P}=0.536), \mathrm{AMG}$ (Fig. 1F; $\mathrm{t}=0.976, \mathrm{df}=13, \mathrm{P}=0.347$ ), POA (Fig. $1 \mathrm{I} ; \mathrm{t}=0.976, \mathrm{df}=13, \mathrm{P}=0.347$ ), $\mathrm{SCN}$ (Fig. $1 \mathrm{~L} ; \mathrm{t}=-0.304, \mathrm{df}=13, \mathrm{P}=0.766)$, or $\mathrm{VH}($ Fig. $1 \mathrm{O} ; \mathrm{t}=-0.245, \mathrm{df}=10, \mathrm{P}=0.811)$. Body size did not differ significantly between treatment groups $(\mathrm{t}=0.127, \mathrm{df}=15, \mathrm{p}=$ 0.901). In contrast to previous studies, I observed very few vasotocin-ir cells in the NAcc in both treatment groups. Most males showed no stained somata in the NAcc, although some fibres were observed toward the caudal end of the NAcc. In animals where staining was observed, only one to three vasotocin-ir cells were observed (fig. 1A, E).

\section{Experiment 2: Seasonal and Sex Variation in MT1-ir cells}

I observed MT1-ir staining in many regions throughout the brain of green treefrogs (Fig. 2). As expected, all staining disappeared when the primary antibody was pre-absorbed with $6 \mu \mathrm{g}$ MT1 peptide per ml antiserum (Figure 3). In this study, I quantified MT1-ir cell bodies in brain regions known to contain vasotocin cell or fiber populations, including the NAcc, AMG, POA, SCN, and VH. Rostrally, cells were quantified in the diagonal band of Broca, the NAcc, and the medial and lateral septum. However, there were no discernable boundaries between any of these regions, and therefore I counted all cells in these areas as a group designated the NAcc region. Similarly, due to the high numbers of cells in both the POA and the SCN, and the lack of a distinct rostrocaudal boundary between these cell populations, the POA and SCN were counted as one population. Cell bodies were also quantified in the medial and lateral 
amygdala (AMG), the dorsal and ventral striatum (STR), and the ventral hypothalamus (VH). I observed variable morphology in stained cells, suggesting that MT1-ir cell counts include both glial cells and neurons.

Body size (measured as snout-urostyle length and used as a proxy for brain size) did not vary significantly between $\operatorname{sex}\left(\mathrm{F}_{1,30}=0.0274, \mathrm{p}=0.870\right)$ or season $\left(\mathrm{F}_{1,30}=\right.$ $0.0004, \mathrm{p}=0.958)$. The interaction term was also statistically non-significant $\left(\mathrm{F}_{1,30}=\right.$ $1.215, \mathrm{p}=0.280$ ). Data from nonreproductive females are included in figures for reporting purposes and comparison to males, but I excluded from statistical analyses due to low sample sizes. 


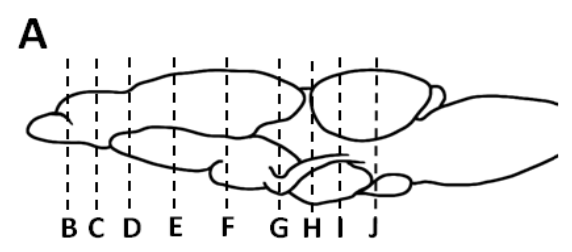

B

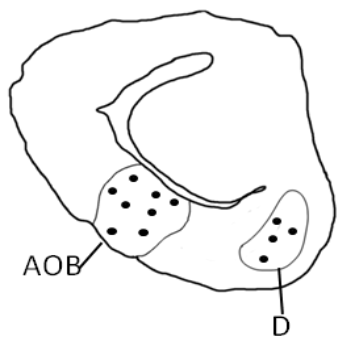

$\mathrm{E}$

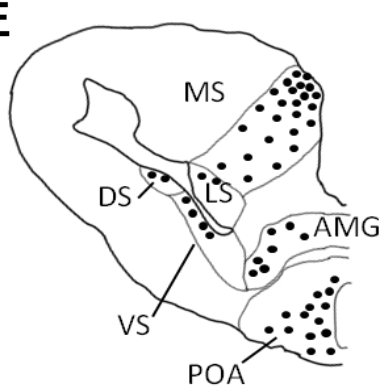

$\mathrm{H}$

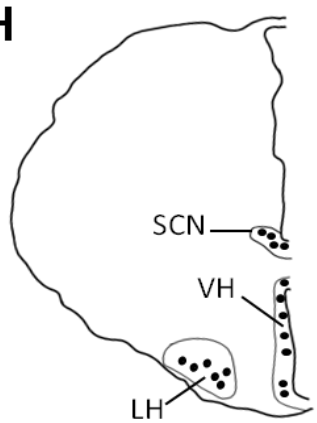

C

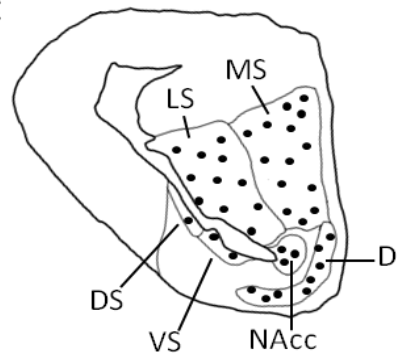

D

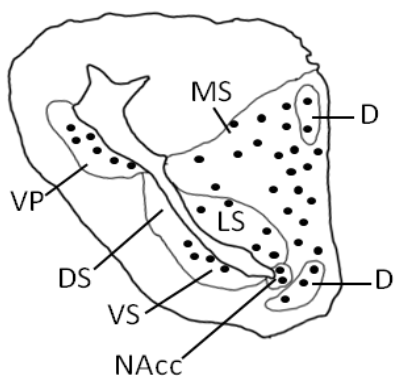

$\mathbf{F}$

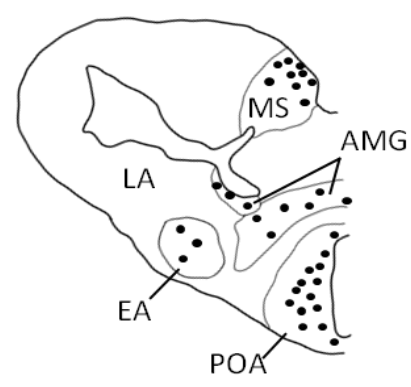

G
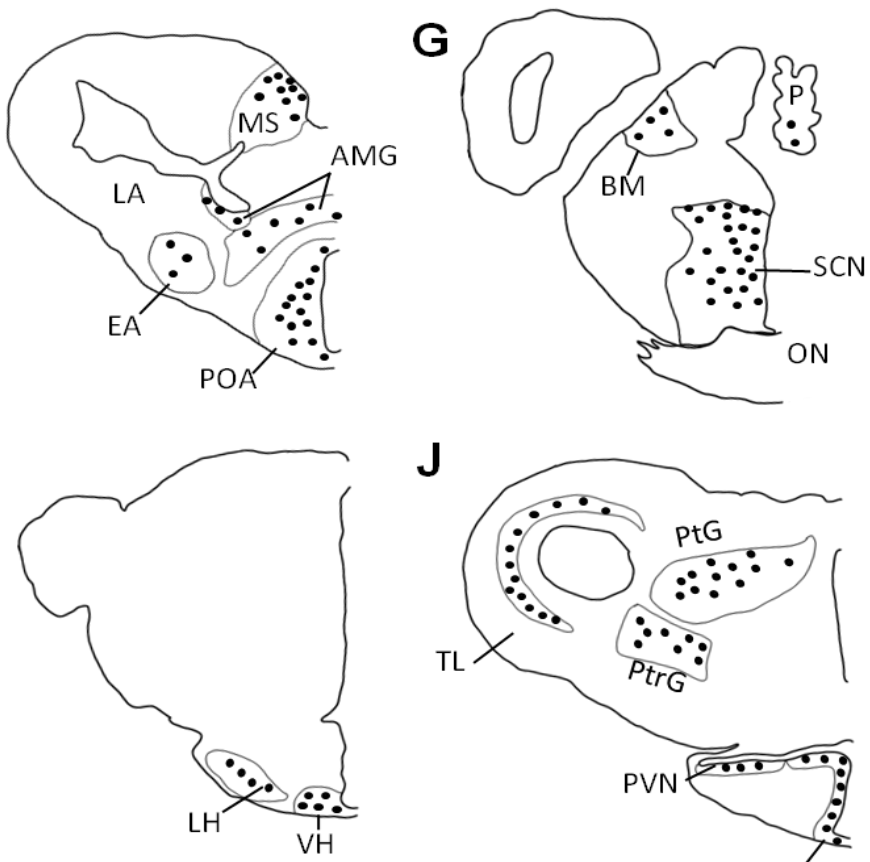

J

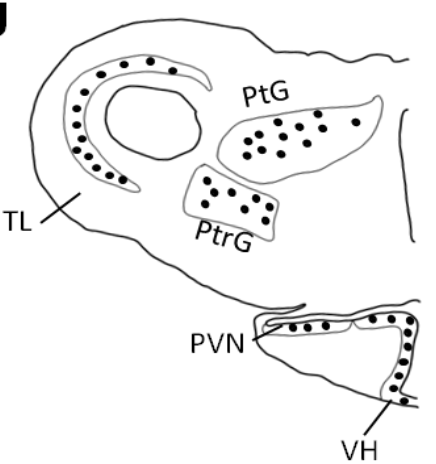

Fig. 2. Distribution of all observed MT1 immunoreactivity in green treefrogs (Hyla cinerea) across sex and season. A. Schematic showing the sagittal view of the frog brain (redrawn from (1), the rostral portion of the brain is oriented to the left. The dotted vertical lines denote the level of sections through MT1 cell populations. B-J: Drawings of coronal sections through the brain show the locations of MT1-ir somata as dots within denoted brain regions: (AOB), diagonal band of Broca (D), medial (MS) and lateral (LS) septum, dorsal (DS) and ventral (VS) striatum, nucleus accumbens (NAcc), and ventral pallium (VP), medial (MS) and lateral (LS) septum, dorsal (DS) and ventral (VS) striatum, medial and lateral amygdala (AMG), pre-optic area (POA), anterior enteropeduncular nucleus (EA), suprachiasmatic nucleus ( $\mathrm{SCN}$ ), bed nucleus of the stria medullaris (BM), and pineal gland (P). Optic nerve labelled for reference $(\mathrm{ON})$, no immunoreactivity observed. H-J: Suprachiasmatic nucleus, lateral (LH) and ventral hypothalamus $(\mathrm{VH})$, periventricular nucleus $(\mathrm{PVN})$, pretoral $(\mathrm{PtrG})$ and pretectal $(\mathrm{PtG})$ grey matter, and tectal laminae (TL) 

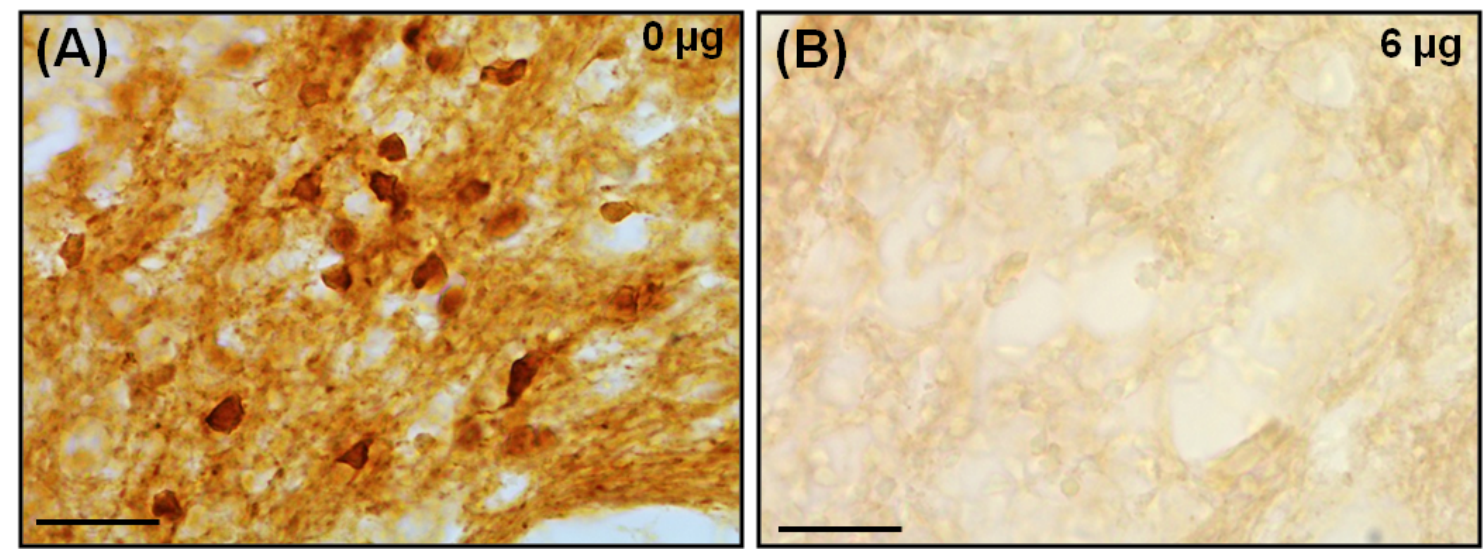

Fig. 3. Example photomicrographs of MT1 antiserum preabsorption tests. Immunoreactive staining is shown following preabsorption of the antiserum (1:500 dilution) with (A) 0, or (B) 6, $\mu$ g MT1 peptide. Scale bars $=$ $50 \mu \mathrm{m}$.

In all regions in which MT1-ir cells were quantified, reproductively active, summer-acclimated males had significantly more MT1-ir cells than non-reproductive, winter-acclimated males (Fig. 4): NAcc $(\mathrm{t}=4.846, \mathrm{df}=15, \mathrm{p}<0.001), \mathrm{STR}(\mathrm{t}=2.63, \mathrm{df}$ $=14, \mathrm{p}=0.020), \operatorname{AMG}(\mathrm{t}=4.011, \mathrm{df}=15, \mathrm{p}=0.001), \mathrm{POA}$ and $\mathrm{SCN}(\mathrm{t}=5.034, \mathrm{df}=16$, $\mathrm{p}<0.001)$, and the VH $(\mathrm{t}=6.084, \mathrm{df}=14, \mathrm{p}<0.001)$.

A within-season sex difference was observed in reproductively active frogs within the NAcc, where males had significantly more MT1-ir cells than females (fig. 4A, $\mathrm{t}=$ 2.463, $\mathrm{df}=11, \mathrm{p}=0.031)$. In contrast, there were no sex differences in MT1-ir cell number in the STR (fig. 5B, $t=0.337$, df $=10, p=0.743$ ), AMG (fig $5 \mathrm{C}, \mathrm{t}=0.285$, $\mathrm{df}=$ $11, \mathrm{p}=0.781$ ), POA and $\mathrm{SCN}$ (fig $5 \mathrm{D}, \mathrm{t}=0.916$, $\mathrm{df}=12, \mathrm{p}=0.377$ ), or the $\mathrm{VH}$ (fig. $5 \mathrm{E}, \mathrm{t}$ $=1.544, \mathrm{df}=8, \mathrm{p}=0.161)$. 


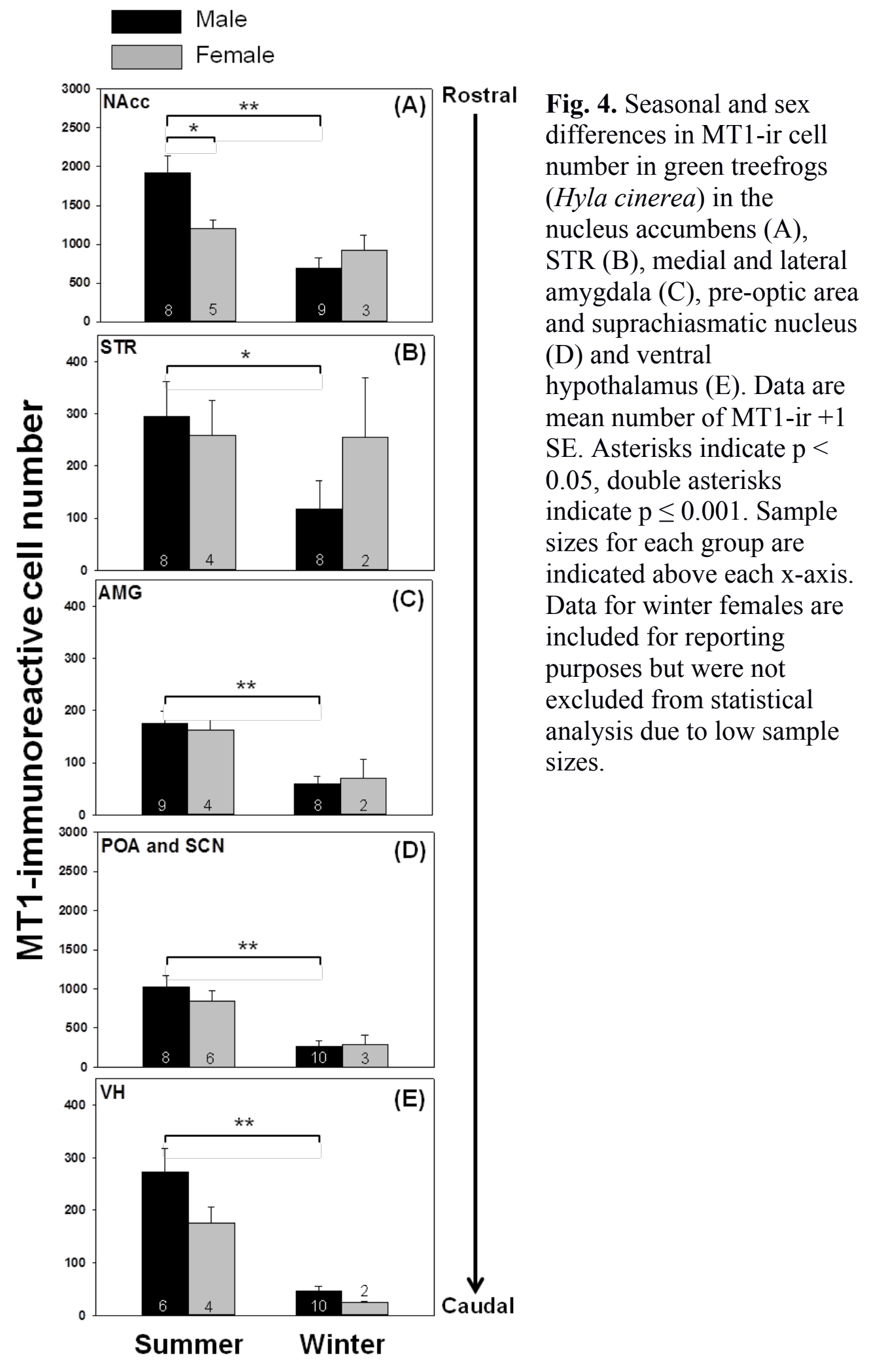




\section{DISCUSSION AND CONCLUSIONS}

Melatonin modulates arginine vasotocin-ir cell number in the brain of male green treefrogs (Hyla cinerea) during the summer breeding season, and this modulation is sexually dimorphic (1). In this study, I demonstrate that melatonin's influence on vasotocin neuron number varies seasonally in males: vasotocin-ir neuron number did not change in response to melatonin treatment in winter-acclimatized, nonreproductive male frogs, but did change in reproductively active summer males (1). Taken together, these results suggest that melatonin's influence on vasotocin may be associated with sex and seasonal variation in melatonin receptor expression. To test this hypothesis, I characterized the distribution of MT1 peptide across sex and season in regions known to contain vasotocin cell and fibre populations. Our results demonstrate that reproductive, summer-acclimated males had significantly more MT1-ir cells than nonreproductive, winter-acclimated males in all brain regions, including the NAcc, STR, AMG, $\mathrm{POA} / \mathrm{SCN}$, and VH. In the NAcc region, where melatonin's effect on vasotocin is known to be sexually dimorphic during the breeding season (1), males had significantly more MT1-ir cells than females during the summer breeding season. I suggest that MT1 plays a role in mediating the interactions between melatonin and vasotocin that regulate seasonal and sexually dimorphic changes in social reproductive behavior.

\section{Seasonal and Sex Differences in Vasotocin/Vasopressin: Regulation by Melatonin}

The vasotocin/vasopressin neuropeptide system is a well-known modulator of social and reproductive behavior (22). Seasonal variation in the vasotocin/vaso 
neuropeptide system has been extensively documented in a variety of vertebrates, and higher vasotocin/vasopressin neuron number during the breeding season is often observed $(22,25,42)$. Sex dimorphism in brain vasotocin is also widespread; males typically have more and/or larger vasotocin/vasotocin neurons than females $(1,22)$. Based on these observations, sex steroid hormones have been suggested as potential mediators of seasonal and sex variation in vasotocin/vaso. Increases in brain vasotocin/vasotocin are frequently concomitant with seasonal increases in androgen concentrations $(22,25,55)$. However, socially-induced increases in testosterone do not influence brain vasotocin in males in at least two species: green anoles (Anolis carolinensis) and green treefrogs (Hyla cinerea) $(25,56)$. Further, though Lutterschmidt and Wilczynski (2012) found that although treatment with exogenous melatonin decreased vasotocin-ir cell number in the brain of green treefrogs, it did not influence plasma concentrations of sex steroid hormones. These results suggest that fluctuations in sex steroid hormones are not the primary mechanism driving seasonal variation in vasotocin-ir cell number. Rather, several studies have demonstrated that seasonal and sex differences in vasotocin/vasopressin may be mediated by the pineal hormone melatonin $(1,20,43,57)$.

The indoleamine hormone melatonin is an endocrine transducer of photoperiod and temperature, and entrains endogenous rhythms to changing environmental contexts (3). Not only does melatonin influence reproduction in many vertebrate taxa $(1,6,58)$, but it has also been shown to modulate brain vasotocin in both in vivo and in vitro studies $(1,59)$. Accordingly, melatonin is a good candidate as a direct regulator of seasonal changes in brain vasotocin as it relates to reproduction. Recently, Lutterschmidt and Wilczynski (2012) showed that treatment of reproductively active male green tree frogs 
(Hyla cinerea) with melatonin significantly decreased vasotocin-ir cell number in the NAcc and the SCN, but not in the POA, AMG or VH. Additionally, reproductively active female frogs were insensitive to melatonin in all vasotocin neuron populations. In the present study, I show that treatment with melatonin does not influence vasotocin-ir cell number in any vasotocin population in nonreproductive male $H$. cinerea. Taken together, these results indicate that melatonin inhibits vasotocin during the breeding season in male green treefrogs, but not during the non-breeding season or in females.

It is possible that differences in melatonin's influence on vasotocin-ir cell number between Lutterschmidt and Wilczynski (2012) and our study are an artifact of using different populations of treefrogs. Hyla cinerea in this study were collected from natural breeding populations in Louisiana, while frogs in Lutterschmidt and Wilczynski (2012) were collected from natural breeding populations in Georgia. However, this degree of divergence seems unlikely at the population level, especially given that locations of vasotocin/vasopressin neurons are well conserved across vertebrates, including treefrogs $(1,22,23,25)$.

It is worth noting that I observed a paucity of vasotocin-ir cells in the NAcc in winter-acclimated male frogs regardless of treatment condition. The NAcc is a brain region associated with appetitive reproductive and social behavior in vertebrates, including anurans $(23,60)$. It is possible that the observed scarcity of vasotocin-ir neurons in the NAcc in winter-acclimated males in this study is related to their nonreproductive state. A related observation in European hamsters (Cricetus cricetus) supports this notion: dense, sexually dimorphic vasotocin innervation present in 
reproductively active male hamsters during spring is almost completely absent in autumn, just before hibernation (61). Thus, marked reduction and subsequent recrudescence of vasotocin/vasopressin innervation associated with changes in reproductive state may also be a conserved feature of this neuropeptide system. Further studies are necessary to evaluate this hypothesis.

\section{Sex and Seasonal Variation in Melatonin Receptor 1a}

Vasotocin neuron populations exhibit seasonal and sex variation in their responses to melatonin, therefore I postulated that these results might reflect variation in melatonin receptor density and/or distribution in the brain. Like most vertebrates, anuran amphibians possess three subtypes of membrane-bound, G-protein coupled melatonin receptors: Mel1a, Mel1b, and Mel1c (MT1, MT2, and MT3 in mammals) (62-64). Recent studies indicate that the MT1 receptor is the subtype responsible for regulating neuroendocrine changes associated with seasonal reproduction $(45,46)$. Further, in Siberian hamsters (Phodopus sungorus) and humans (Homo sapiens), MT1 receptors have been shown to localize within vasopressin neurons in the suprachiasmatic nucleus $(47,48)$, suggesting that melatonin can directly modulate vasopressin neurons via a receptor-mediated mechanism.

I sought to characterize the distribution of MT1-ir cells in pursuit of understanding the mechanism by which melatonin regulates vasotocin in green treefrogs. I found significantly higher numbers of MT1-ir cells in all brain regions of reproductively active males compared to nonreproductive males. These results indicate that in male $H$. cinerea, brain vasotocin cell populations are more sensitive to melatonin signalling 
during the summer breeding season than they are during the non-reproductive months. Thus, MT1 receptors may be integrating vasotocin/vasopressin-mediated changes in social reproductive behavior with changing environmental conditions. In support of this hypothesis, two mammals possessing only functional MT1 receptors, Siberian hamsters (Phodopus sungorus) (46) and Dorset ewes (65), still exhibit photoperiodic breeding. Thus far, no evidence of an interaction between vasopressin and MT1 has been observed in sheep, but in Siberian hamsters, MT1 receptors localize within vasopressin neurons (47), and administration of a MT1 receptor agonist under long-day conditions induces gonadal regression, reduced gonadotrophin secretion and other indicators of transition to a non-reproductive state (46).

Previous studies have demonstrated that like cricket frogs (Acris crepitans) reproductive male green treefrogs have significantly more vasotocin-ir cells in the NAcc than reproductive females $(1,23)$, and our study shows that the same is true for MT1-ir cells. The NAcc is associated with appetitive and consummatory reproductive behavior in vertebrates, including advertisement calling $(23,60,66,67)$. Only male green treefrogs produce advertisement calls (44), therefore it is likely that the sex differences in the response of vasotocin neurons to melatonin reflect the sexually dimorphic mating strategies in this species, particularly during the appetitive phase. A similar finding in house sparrows (Passer domesticus) showed sexually dimorphic binding of 2[125I]iodomelatonin (IMEL), an indicator of melatonin sensitivity, in the brain. In this study, male house sparrows showed IMEL binding in areas critical to song control, while females lacked IMEL binding in these areas (68). Like anurans, vasotocin is known to regulate advertisement calling in seasonally breeding passerine birds $(69,70)$, and in both 
groups, calling must occur at specific times of day. Therefore, it is possible that the increased melatonin sensitivity in brain regions related to appetitive sexual behavior like reproductive vocalization is related to seasonal regulation of advertisement call production.

Although the vasotocin/vasopressin system is very well studied, most studies have focused on males. In anurans and urodeles, sex dimorphism in brain vasotocin tends to be male-biased $(23,28,71)$, and treatment of males with vasotocin facilitates or increases male reproductive behaviors $(23,24,34,38,39,41,72)$. However, vasotocin can, for example, induce phonotaxis and inhibit release calling in female bullfrogs (Lithobates catesbeiana) $(27,71)$. Although vasotocin may regulate related aspects of social reproductive behavior in some male and female amphibians, in general nonapeptide regulation of female reproductive behavior remains enigmatic (e.g., Wilczynski et al. 2005). For example, Lutterschmidt and Wilczynski (2012) showed that melatonin does not alter brain vasotocin in female green treefrogs, suggesting that females do not exhibit seasonal changes in vasotocin-ir cell number. Moreover, relative to male $H$. cinerea, females also showed very little seasonal variation in MT1 immunoreactivity in the NAcc and STR (but note small sample sizes of nonreproductive females). Further studies are necessary to understand the role of the vasotocin/vasopressin system in female reproductive behavior, as well as if and how melatonin and MT1 mediate seasonal changes in vasotocin/vasopressin in other vertebrate systems.

In contrast to the NAcc, no sex differences in MT1-ir cell number were observed in reproductive frogs in the $\mathrm{STR}, \mathrm{AMG}, \mathrm{POA} / \mathrm{SCN}$, or $\mathrm{VH}$. Our results corroborate those of Lutterschmidt and Wilczynski (1), where the effect of melatonin on vasotocin-ir cells 
did not vary with sex during the breeding season in the AMG, POA, or VH. The AMG is associated with sexual behavior, fear, and aggression, while the POA and VH are involved in regulation of water balance and production and secretion of neurohypophyseal hormones, respectively. Thus, lack of sexual dimorphism in these regions both in vasotocin's response to melatonin, and MT1-ir cell number may relate to a need to maintain aggressive and/or sexual behaviors and maintain osmotic homeostasis during the breeding season regardless of sex. Very little is known about the specific function of MT1 in brain regions other than the $\mathrm{SCN}$, and much of the recent work on this receptor has been in disease models $(73,74)$. However Imbesi et al. $(2008)$ found that melatonin regulates clock gene expression in in vitro preparations of striatal neurons via MT1 (75). Males and females must occupy the same temporal niche in order to reproduce successfully. Therefore, it is possible that the lack of sexually dimporphic MT1 expression in the striatum during the breeding season represents conserved regulation of non-appetitive biological rhythmicity between sexes.

Within the SCN, melatonin decreases vasotocin-ir cell number in males but not in females during the summer breeding season (1). Based on these results, I hypothesized that I would observe a concomitant sexual dimorphism in MT1 immunoreactivity in this brain region, especially given it's known role in regulation of seasonal reproduction. Unexpectedly, our study shows no sex difference in MT1 immunoreactivity in this region. The SCN are paired nuclei that function as the physiological "master clock"; they entrain endogenous rhythms in other "slave clocks" throughout the vertebrate body (76). The observed sex difference in melatonin's modulation of vasotocin during the breeding season doesn't necessarily require that MT1 cells are sexually dimorphic in this region. It 
is possible that other subtypes of melatonin receptor (i.e. MT2, MT3) are responsible for regulating sex differences in melatonin sensitivity of vasotocin neurons in the SCN. Further studies are necessary to determine if selective melatonin agonists or antagonists produce varied responses in vasotocin-ir cell populations.

Our results indicate that brain vasotocin exhibits reduced sensitivity to melatonin signalling in nonreproductive male green treefrogs. The results from our melatonin receptor assay corroborate this: MT1-ir cell number, thought to be the melatonin receptor regulating seasonal reproduction, is significantly lower in nonreproductive, winteracclimatized frogs compared to reproductively active frogs. I also show that the NAcc, a region known to regulate appetitive sexual behavior, is more sensitive to melatonin signalling in reproductively active males than in reproductively active females. Based on these findings, I postulate that melatonin modulates vasotocin directly, with MT1 possibly localizing within vasotocin neurons in green treefrogs. Findings in mammals support this hypothesis: Vasotocin and MT1 mRNA are co-expressed in SCN cells in Siberian hamsters (Phodopus sungorus) (47). At the peptide level, co-occurrence of vasotocin and MT1 immunoreactivity within the same neurons has also been shown in the human SCN, and also in the parvocellular and magnocellular POA (48). Collectively, these results suggest that melatonin modulates brain vasotocin via MT1. Further studies are necessary to determine at what levels melatonin regulates brain vasotocin/vasopressin in vertebrates. This will further elucidate the neuroendocrine mechanisms by which vertebrates integrate seasonal cues to correctly time critical life history events such as reproduction. 


\section{REFERENCES}

1.Lutterschmidt DI, Wilczynski W. Sexually dimorphic effects of melatonin on brain arginine vasotocin immunoreactivity in green treefrogs (Hyla cinerea). Brain, behavior and evolution. 2012; 80(3): 222-32.

2.Hegyi G, Nagy G, Torok J. Reduced compensatory growth capacity in mistimed broods of a migratory passerine. Oecologia. 2013; 172(1): 279-91.

3.Hazlerigg DG, Wagner GC. Seasonal photoperiodism in vertebrates: from coincidence to amplitude. Trends in endocrinology and metabolism: TEM. 2006; 17(3): 83-91. 4.Prendergast BJ. Internalization of seasonal time. Hormones and behavior. 2005; 48(5): 503-11.

5.Cassone VM, Natesan AK. Time and Time Again: The Phylogeny of Melatonin as a Transducer of Biological Time. Journal of biological rhythms. 1997; 12(6): 489-97. 6.Mayer I, Bornestaf C, Borg B. Melatonin in Non-Mammalian Vertebrates: Physiological Role in Reproduction? Comparative Biochemistry and Physiology. 1997; 118A(3): 515-31.

7.Rensing L, Ruoff P. Temperature Effect on Entrainment, Phase Shifting, and Amplitude of Circadian Clocks and Its Molecular Bases. Chronobiology International. 2002; 19(5): 807-64.

8.Vivien-Roels B, Pevet P, Dubois M, Arendt J, Brown G. Immunohistochemical evidence for the presence of melatonin in the pineal gland, the retina and the Harderian gland. Cell and tissue research. 1981; 217(1): 105-15.

9.Cassone VM. Effects of Melatonin on Vertebrate Circadian Systems. Trends in Neuroscience. 1990; 13(11): 457-64.

10.Kumar V. Melatonin: a master hormone and a candidate for universal panacea. Indian journal of experimental biology. 1996; 34(5): 391-402.

11.Tilden AR, Hutchison VH. Influence of Photoperiod and Temperature on Serum Melatonin in the Diamondback Water Snake, Nerodia rhombifera. General and comparative endocrinology. 1993; 92(3): 347-54.

12.Lutterschmidt DI, Mason RT. Geographic variation in timekeeping systems among three populations of garter snakes (Thamnophis sirtalis) in a common garden. Physiological and biochemical zoology : PBZ. 2008; 81(6): 810-25.

13. Revel FG, Masson-Pévet M, Pévet P, Mikkelsen JD, Simonneaux V. Melatonin controls seasonal breeding by a network of hypothalamic targets. Neuroendocrinology. 2009; 90(1): 1-14.

14. Rosa HJD, Bryant MJ. Seasonality of reproduction in sheep. Small Ruminant Research. 2003; 48(3): 155-71.

15.Bittman EL, Karsch FJ. Nightly duration of pineal melatonin secretion determines the reproductive response to inhibitory day length in the ewe. Biology of reproduction. 1984; 30(3): 585-93.

16. Robinson JE, Karsch FJ. Refractoriness to inductive day lengths terminates the breeding season of the Suffolk ewe. Biology of reproduction. 1984; 31(4): 656-63. 
17. Yellon S, Bittman E, Lehman M, Olster D, Robinson J, Karsch F. Importance of duration of nocturnal melatonin secretion in determining the reproductive response to inductive photoperiod in the ewe. Biology of reproduction. 1985; 32(3): 523-9.

18.Underwood H. Effects of pinealectomy and melatonin on the photoperiodic gonadal response of the male lizard Anolis carolinensis. Journal of Experimental Zoology. 1981; 217(3): 417-22.

19.Boczek-Leszczyk E, Stempmiak B, Juszcak M. Vasopressin release from the rat hypothalamo-neurohypophysial system: effects of gonadotrophin-releasing hormone (GNRH), its analogues and melatonin. Journal of Physiology and Pharmacology. 2010; 61(4): 459-66.

20.Juszcak M, Stempmiak B. Melatonin inhibits the substance P-induced secretion of vasopressin and oxytocin from the rat hypothalamo-neurohypophyseal system: In vitro studies. Brain Research Bulletin. 2003; 59(5): 393-7.

21.Juszczak M, Boczek-Leszczyk E. Hypothalamic gonadotropin-releasing hormone receptor activation stimulates oxytocin release from the rat hypothalamoneurohypophysial system while melatonin inhibits this process. Brain Res Bull. 2010; 81(1): 185-90.

22. Goodson JL, Bass AH. Social behavior functions and related anatomical characteristics of vasotocin/vasopressin systems in vertebrates. Brain Research Reviews. 2001; 35(3): 246-65.

23.Marler CA, Boyd SK, Wilczynski W. Forebrain Arginine Vasotocin Correlates of Alternative Mating Strategies in Cricket Frogs. Hormones and Behavior . 1999; 36(1): 53-61.

24.Marler CA, Chu J, Wilczynski W. Arginine vasotocin injection increases probability of calling in cricket frogs, but causes call changes characteristic of less aggressive males. Hormones and behavior. 1995; 29(4): 554-70.

25.O'Bryant EL, Wilczynski W. Changes in plasma testosterone levels and brain AVT cell number during the breeding season in the green treefrog. Brain, behavior and evolution. 2010; 75(4): 271-81.

26.Bargmann W, Scharrer E. The site of origin of the hormones of the posterior pituitary. American scientist. 1951; 39(2): 255-9.

27. Boyd SK. Brain Vasotocin Pathways and the Control of Sexual Behaviors in the Bullfrog. Brain Research Bulletin. 1997; 44(4): 345-50.

28. Boyd SK, Moore FL. Sexually dimorphic concentrations of arginine vasotocin in sensory regions of the amphibian brain Brain research. 1992; 325(2): 304-6.

29.Mühlethaler M, Charpak S, Dreifuss J-J. Contrasting effects of neurohypophysial peptides on pyramidal and non-pyramidal neurones in the rat hippocampus. Brain research. 1984; 308(1): 97-107.

30.Castillo - Romero J, Vives - Montero F, Reiter R, Acuña - Castroviejo D. Pineal modulation of the rat caudate - putamen spontaneous neuronal activity: Roles of melatonin and vasotocin. Journal of pineal research. 1993; 15(3): 147-52.

31.Goodson JL, Thompson RR. Nonapeptide mechanisms of social cognition, behavior and species-specific social systems. Current opinion in neurobiology. 2010; 20(6): 78494. 
32. Boyd SK. Arginine vasotocin facilitation of advertisement calling and call phonotaxis in bullfrogs. Hormones and behavior. 1994; 28(3): 232-40.

33. Chu J, Marler CA, Wilczynski W. The Effects of Arginine Vasotocin on the Calling Behavior of Male Cricket Frogs in Changing Social Contexts. Hormones and behavior. 1998; 34(3): 248-61.

34. Moore FL, Miller LJ. Arginine vasotocin induces sexual behavior of newts by acting on cells in the brain Peptides. 1983; 4(1): 97-102.

35.Penna M, Capranica RR, Somers J. Hormone-induced vocal behavior and midbrain auditory sensitivity in the green treefrog, Hyla cinerea. Journal of Comparative Physiology A. 1992; 170(1): 73-82.

36.Propper CR, Dixon TB. Differential Effects of Arginine Vasotocin and GonadotropinReleasing Hormone on Sexual Behaviors in an Anuran Amphibian Hormones and behavior. 1997; 32(2): 99-104.

37. Semsar K, Kandel FL, Godwin J. Manipulations of the AVT system shift social status and related courtship and aggressive behavior in the bluehead wrasse. Hormones and behavior. 2001; 40(1): 21-31.

38.Semsar K, Klomberg KF, Marler CA. Arginine vasotocin increases calling-site acquisition by nonresident male grey treefrogs. Animal behaviour. 1998; 56(4): 983-7. 39.Ten Eyck GR. Arginine vasotocin activates advertisement calling and movement in the territorial Puerto Rican frog, Eleutherodactylus coqui. Hormones and behavior. 2005; 47(2): 223-9.

40.Kime NM, Whitney TK, Ryan MJ, Rand AS, Marler CA. Treatment with arginine vasotocin alters mating calls and decreases call attractiveness in male tungara frogs. General and comparative endocrinology. 2010; 165(2): 221-8.

41.Thompson R, Moore F. Vasotocin stimulates appetitive responses to the visual and pheromonal stimuli used by male roughskin newts during courtship. Hormones and behavior. 2000; 38(2): 75-85.

42. Maruska KP, Mizobe MH, Tricas TC. Sex and seasonal co-variation of arginine vasotocin (AVT) and gonadotropin-releasing hormone (GnRH) neurons in the brain of the halfspotted goby. Comparative biochemistry and physiology Part A, Molecular \& integrative physiology. 2007; 147(1): 129-44.

43.Juszcak M, Boczek-Leszczyk E, Stempmiak B. Effect of Melatonin on the Vasopressin Secretion as Influenced by Tachykinin NK-1 Receptor Agonist and Antagonist: In Vivo and In Vitro Studies. Journal of Physiology and Pharmacology. 2007; 58(4): 829-43.

44. Garton JS, Brandon RA. Reproductive Ecology of the Green Treefrog (Hyla cinerea) in Southern Illinois (Anura: Hylidae). Herpetologica. 1975; 31(2): 150-61. 45. Chai K, Liu X, Zhang Y, Lin H. Day-night and reproductive cycle profiles of melatonin receptor, kiss, and gnrh expression in orange-spotted grouper (Epinephelus coioides). Molecular reproduction and development. 2013; 80(7): 535-48. 46.Prendergast BJ. MT1 melatonin receptors mediate somatic, behavioral, and reproductive neuroendocrine responses to photoperiod and melatonin in Siberian hamsters (Phodopus sungorus). Endocrinology. 2010; 151(2): 714-21. 
47. Song CK, Bartness TJ, Petersen SL, Bittman EL. Co-Expression of Melatonin (MEL1a) Receptor and Arginine Vasopresin mRNAs in the Siberian Hamster Suprachiasmatic Nucleus. Journal of neuroendocrinology. 2000; 12(7): 627-34. 48.Wu YH, Zhou JN, Balesar R, Unmehopa U, Bao A, Jockers R, Van Heerikhuize J, Swaab DF. Distribution of MT1 melatonin receptor immunoreactivity in the human hypothalamus and pituitary gland: colocalization of MT1 with vasopressin, oxytocin, and corticotropin-releasing hormone. The Journal of comparative neurology. 2006; 499(6): 897-910.

49. Boyd SK, Tyler CJ, de Vries GJ. Sexual dimorphism in the vasotocin system of the bullfrog (Rana catesbeiana) Journal of Comparative Neurology. 1992; 325(2): 313-25. 50.Mathieson WB. Development of arginine vasotocin innervationin two species of anuran amphibian: Rana catesbeiana and Rana sylvatica. Histochemistry and Cell Biology. 1996; 105(4): 305-18.

51.Wiechmann AF, Vrieze MJ, Wirsig-Wiechmann CR. Differential distribution of melatonin receptors in the pituitary gland of Xenopus laevis. Anatomy and embryology. 2003; 206(4): 291-9.

52.Kumar Kharwar R, Haldar C. Anatomical and histological profile of bronchusassociated lymphoid tissue and localization of melatonin receptor types (Mel 1a and Mel 1b) in the lung-associated immune system of a tropical bird, Perdicula asiatica. Acta histochemica. 2011; 113(3): 333-9.

53. Neary TJ, Northcutt RG. Nuclear organization of the bullfrog diencephalon. Journal of Comparative Neurology. 1983; 213(3): 262-78.

54.Wilczynski W, Northcutt RG. Connections of the bullfrog striatum: afferent organization. Journal of Comparative Neurology. 1983; 214(3): 321-32.

55.De Vries GJ, Panzica GC. Sexual differentiation of central vasopressin and vasotocin systems in vertebrates: different mechanisms, similar endpoints. Neuroscience. 2006; 138(3): 947-55.

56.Hattori T, Wilczynski W. Comparison of arginine vasotocin immunoreactivity differences in dominant and subordinate green anole lizards. Physiology \& behavior. 2009; 96(1): 104-7.

57.Bojanowska E, Forsling ML. The effects of melatonin on vasopressin secretion in vivo: interactions with acetylcholine and prostaglandins. Brain research bulletin. 1997; 42(6): 457-61.

58. Revel FG, Masson-Pevet M, Pevet P, Mikkelsen JD, V. S. Melatonin controls seasonal breeding by a network of hypothalamic targets. Neuroendocrinology. 2009; 90(1): 1-14.

59.Isobe Y, Torii T, Nishino H. Melatonin inhibits Arg-vasopressin release via MT2 receptor in the suprachiasmatic nucleus-slice culture of rats. Brain research. 2001; 889(1): 214-9.

60. Salamone JD. The involvement of nucleus accumbens dopaine in appetitive and aversive motivation. Behavioural Brain Research. 1994; 61(2): 117-33.

61.Buijs RM, Pevet P, Masson-Pevet M, Pool CW, de Vries GJ, Canguilhem B, ViventRoels B. Seasonal variation in vasopressin innervation in the brain of the European hamster (Cricetus cricetus). Brain research. 1986; 371(1): 193-6. 
62.Reppert SM, Weaver DR, Cassone VM, Godson C, Kolakowski LFJ. Melatonin Receptors are for the Birds: Molecular Analysis of Two Receptor Subtypes Differentially Expressed in Chick Brain. Neuron. 1995; 15(5): 1003-15.

63. Wiechmann AF, Smith AR. Melatonin Receptor RNA is expressed in photoreceptors and displays a diurnal rhythm in Xenous retina. Molecular Brain Research 2001; 91(1): 104-11.

64. Wiechmann AF, Udin SB, Summers Rada JA. Localization of Mel1b melatonin receptor-like immunoreactivity in ocular tissues of Xenopus laevis. Experimental Eye Research. 2004; 79(4): 585-94.

65. Mateescu RG, Lunsford AK, Thonney ML. Association between melatonin receptor 1A gene polymorphism and reproductive performance in Dorset ewes. Journal of animal science. 2009; 87(8): 2485-8.

66. Salamone JD, Correa M, Mingote SM, Weber SM. Beyond the reward hypothesis: alternative functions of nucleus accumbens dopamine. Current opinion in pharmacology. 2005; 5(1): 34-41.

67.Pfaus JG, Damsma G, Wenkstern D, Fibiger HC. Sexual activity increases dopamine transmission in the nucleus accumbens and striatum of female rats. Brain research. 1995; 693(1): 21-30.

68. Whitfield-Rucker MG, Cassone VM. Melatonin Binding in the House Sparrow Song Control System: Sexual dimorphism and the Effect of Photoperiod. Hormones and behavior. 1996; 30(4): 528-37.

69.Goodson J, Adkins-Regan E. Effect of intraseptal vasotocin and vasoactive intestinal polypeptide infusions on courtship song and aggression in the male zebra finch (Taeniopygia guttata). Journal of neuroendocrinology. 1999; 11 (0): 19-26. 70.Goodson JL. Territorial Aggression and Dawn Song are Modulated by Septal Vasotocin and Vasoactive Intestinal Polypeptide in Male Field Sparrows Spizella pusilla. Hormones and behavior. 1998; 34(1): 67-77.

71. Boyd SK. Arginine vasotocin facilitation of advertisement calling and call phonotaxis in bullfrogs. Hormones and behavior. 1994(28): 232-40.

72. Tito M. AVT Increases Mate Calling Probability in the Adult Male Gray Tree Frog. Notre Dame, IN 1996.

73. Adi N, Mash DC, Ali Y, Singer C, Shehadeh L, Papapetropoulos S. Melatonin MT1 and MT2 receptor expression in Parkinson's disease. Medical science monitor: international medical journal of experimental and clinical research. 2010; 16(2): BR617.

74.Wu Y-H, Zhou J-N, Van Heerikhuize J, Jockers R, Swaab DF. Decreased MT1 melatonin receptor expression in the suprachiasmatic nucleus in aging and Alzheimer's disease. Neurobiology of aging. 2007; 28(8): 1239-47.

75.Imbesi M, Arslan AD, Yildiz S, Sharma R, Gavin D, Tun N, Manev H, Uz T. The melatonin receptor MT1 is required for the differential regulatory actions of melatonin on neuronal 'clock'gene expression in striatal neurons in vitro. Journal of pineal research. 2009; 46(1): 87-94.

76. Reppert SM, Weaver DR. Coordination of circadian timing in mammals. Nature. 2002; 418(6901): 935-41. 